\title{
ENVIRONMENTAL SENSITIVITY INDEX FOR OIL SPILLS IN MARINE AND COASTAL AREAS IN COLOMBIA
}

\author{
ÍNDICES DE SENSIBILIDAD AMBIENTAL ANTE DERRAMES DE HIDROCARBUROS \\ EN LAS ÁREAS MARINAS Y COSTERAS DE COLOMBIA
}

\author{
Diego L. Gil-Agudelo ${ }^{1 *}$, Ramón-Alberto Nieto-Bernal ${ }^{2}$, Diana-Marcela Ibarra-Mojica ${ }^{2}$, \\ Ana-María Guevara-Vargas ${ }^{2}$ and Erich Gundlach ${ }^{3}$ \\ 'Ecopetrol S.A. - Instituto Colombiano del Petróleo (ICP), Piedecuesta, Santander, Colombia \\ ${ }^{2}$ CTP LTDA, Piedecuesta, Santander, Colombia \\ ${ }^{3}$ E-Tech International Inc. Boulder, Colorado, USA \\ e-mail: diego.gil@ecopetrol.com.co
}

(Received: Jan. 20, 2015; Accepted: Jun. 08, 2015)

\begin{abstract}


The implementation of tools to prevent and mitigate the potential impact of oil spills in marine and coastal environments is an issue of interest not only for oil and gas companies, but also for environmental authorities and the general society of the country as they seek to avoid possible damages to the natural realm and human-use resources of an area affected by these events. One of these tools that is useful both for planning and response of oil spills is the Environmental Sensitivity Index (ESI), which establishes the degree of sensitivity of different coastal areas depending on their geophysics, hydrodynamic and biological characteristics. ESI contributes and prioritize to improve response actions to minimize potential environmental impacts. This index is a key element for the construction of the Environmental Sensitivity Maps for oil spills (ESM), but for its correct application, it has to be adjusted to the needs and conditions of each country. This paper presents the adaptation of the ESI for Colombian coastal environments, which has been constructed through the revision of experiences in other countries and the collaboration of national and international experts during workshops. The ESI presented here is the main tool for the elaboration of ESM for Colombia, an instrument that will help in the planning and response process for oil spills in the country.
\end{abstract}

Keywords: Environmental sensitivity maps, Oil spills, Permeability, Biodiversity, Geomorphology, Contingency plans, Socioeconomic resources.

How to cite: Gil-Agudelo, D. L., Nieto-Bernal, R. A., Ibarra-Mojica, D. M., Guevara-Vargas, A. M. \& Gundlach, E. (2015). Environmental sensitivity index for oil spills in marine and coastal areas in Colombia. CT\&F - Ciencia, Tecnología y Futuro, $6(1), 17-28$.

*To whom correspondence should be addressed 


\title{
RESUMEN
}

L

a implementación de herramientas para prevenir y mitigar el potencial impacto de los derrames de hidrocarburos en ambientes costeros es un tema de interés no sólo para las compañías de gas y petróleo, sino también para autoridades ambientales y la sociedad en general, ya que ellos buscan evitar y prevenir daños en los ambientes naturales y los recursos de uso humano en áreas afectadas por estos eventos. Una de estas herramientas que es usada tanto para planear como para responder a derrames de hidrocarburos es el Índice de Sensibilidad Ambiental (ESI, de sus siglas en inglés), el cual establece el grado de sensibilidad de diferentes áreas costeras dependiendo de sus características geofísicas, hidrodinámicas y biológicas. El ESI contribuye a priorizar y mejorar las acciones de respuesta y así minimizar el potencial impacto ambiental de estos eventos. Este índice es un elemento clave para la construcción de los Mapas de Sensibilidad Ambiental ante derrames de hidrocarburos (ESM, de sus siglas en inglés), pero para su correcta aplicación deben ser ajustados a las necesidades y condiciones de cada país. Este artículo presenta la adaptación del ESI para los ambientes costeros colombianos, el cual ha sido construido mediante la revisión de experiencias de otros países y en colaboración con expertos nacionales e internacionales a través de talleres. El ESI presentado aquí es la herramienta fundamental para la elaboración de los ESM para Colombia, un instrumento que servirá en el proceso de planificación y respuestas a derrames de hidrocarburos en el país.

Palabras clave: Mapas de sensibilidad ambiental, Derrames de petróleo, Permeabilidad, Biodiversidad, Geomorfología, Planes de contingencia, Recursos socioeconómicos.

\section{RESUMO}

\begin{abstract}
implantação de ferramentas de prevenção e mitigação do impacto potencial dos vazamentos de óleo em ambientes costeiros é uma questão de interesse não apenas para as companhias de gás e óleo, mas também para as autoridades ambientais e a sociedade em geral, sendo que eles procuram evitar e prevenir prejuízos nos ambientes naturais e nos recursos de uso humano nas áreas afetadas por estes eventos. Uma destas ferramentas, que é usada tanto para planejamento quanto para resposta em eventos de vazamento de óleo, é o Índice de Sensibilidade Ambiental (ESI, por suas siglas em inglês), que estabelece o grau de sensibilidade de diferentes áreas costeiras dependendo das características geofísicas, hidrodinâmicas e biológicas da área. O ESI contribui a priorizar e aprimorar as ações de resposta visando minimizar o potencial impacto ambiental destes eventos. Este índice é um elemento chave para a construção dos Mapas de Sensibilidade Ambiental perante derrames de óleo (ESM, por suas siglas em inglês), mas para sua aplicação correte é necessário se adaptar às necessidades e condições de cada país. Este trabalho apresenta a adaptação do ESI aos ambientes costeiros colombianos, sendo construído mediante a revisão de experiências de outros países e em colaboração com especialistas nacionais e internacionais através de oficinas. O ESI ora presentado é a ferramenta fundamental para a elaboração dos EMS para a Colômbia, um instrumento que servirá no processo de planejamento e resposta a vazamentos de óleo no país.
\end{abstract}

Palavras-chave: Mapas de sensibilidade ambiental, Vazamentos de petróleo, Permeabilidade, Biodiversidade, Geomorfologia, Planos de contingência, Recursos socioeconómicos. 


\section{INTRODUCTION}

The impact of oil spills (and other oil products) in the marine and coastal realm is one of the major concerns for ecosystems and services they provide, such as fishery resources, tourism, aquiculture, port activities, among many others (Clark, 1995; Gundlach, 2006; GilAgudelo \& Wells, 2011). Historically, major oils spills in the marine realm have been the result of accidents involving transportation activities through vessels and coastal facilities, but the offshore exploration and production of oil have also caused important impacts to marine and coastal areas (GESAMP, 2007; Griggs, 2011; Upton, 2011).

The risk of spills throughout the chain of production and transportation of oil and by-products, and their potential impact to ecosystems and human resources, requires appropriate contingency plans in order to respond properly and minimize the risk to the environment. One of the most important elements in the process of contingency planning is the definition of the sensitivity of the areas that can be reached by oil spills (Gundlach \& Hayes, 1978; Nansingh \& Jurawan, 1999; Petersen et al., 2002).

The first coastal Environmental Sensitivity Index (ESI) for oil spills was developed in the late 1970s (Gundlach \& Hayes, 1978; ARPEL, 1997), which were later complemented by Geographic Information System (GIS) technology (Petersen et al., 2002) generating what is now known as Environmental Sensitivity Maps for Oil Spills (ESM) in marine and coastal waters. ESM are key for the generation of Contingency Plans because they incorporate the ESI and biological and socioeconomic information of the area, which together help in the decision making process during a spill event (ARPEL, 1997).

One component of the ESI is the scoring of the sensitivity of the different types of coastal ecosystems to oil exposure. This scoring depends on the persistence of oil in the coastal line due to its penetration in the substratum, easy of removal by cleaning crews without causing any additional damage to the ecosystems, and the possible harm to sensitive biological communities or their productivity. Scores are determined by a series of geomorphological elements of the coastline such as the exposure to waves and tidal energy, type of substrate, slope of the coastline, among others (Gundlach \& Hayes, 1978; Petersen et al., 2002; SQA/ MMA, 2004).

IPIECA (The Global Oil and Gas Industry Association for Environmental and Social Issues) states in its guidelines for ESM that the ESI shoreline ranking must be adapted for the conditions of the coastline of each nation and region (IPIECA-IMO-OGP, 2011). Different countries had followed this recommendation when developing their ESM, mainly adapting NOAA's (National Oceanic and Atmospheric Administration) methodology (Jensen, Halls \& Michel, 1998; Gundlach et al., 2001; Adler \& Inbar, 2007; Castañedo et al., 2008) to their own conditions, since it was constructed based on the experience of oil spills around the world involving different types of coastlines and cleaning actions. The approach of this index simplifies its adaptation and application into the ESM, facilitating fieldwork and generating better results in less time (Petersen et al., 2002).

The main goal of this work was to develop an ESI for oil spill for Colombia, with the aim of standardizing this index for application at a national scale so it can be used for the elaboration of ESM and other oil spill contingency planning tools for the country's coastal and marine areas.

\section{METHODS}

In order to construct an ESI for Colombia, two workshops were conducted with national and international experts (including experts in oil spill contingency planning, government organizations and academia). During the first workshop, discussions revolved around the different factors and criteria to be taken into account in order to establish such an index, bearing in mind that geomorphologic, hydrodynamic, and biotic characteristics of the coast line are the main determinants of oil behavior and, for instance, the degree of environmental impact they can cause (Gundlach \& Hayes, 1978; Petersen et al., 2002; SQA/MMA, 2004). 
Table 1. Criteria used for the construction of ESI for the Colombian coastline.

\begin{tabular}{|c|c|c|}
\hline No & \multicolumn{1}{|c|}{ Criteria } & \multicolumn{1}{c|}{ Definition } \\
\hline 1 & Capability to recover from an oil spill. & $\begin{array}{l}\text { Geomorphological characteristics of the coastline that facilitates its } \\
\text { recovery after an oil spill. }\end{array}$ \\
\hline 2 & $\begin{array}{l}\text { Difficulty for contention, recovery or elimination } \\
\text { of spilled oil by cleaning crews. }\end{array}$ & $\begin{array}{l}\text { Physical characteristics of the coastline that restricts its access and } \\
\text { transit, determining the difficulty of oil cleaning recovery by cleaning } \\
\text { crews. }\end{array}$ \\
\hline 3 & Ecological importance. & $\begin{array}{l}\text { Biotic elements present in the coastline that gives a grade of importance } \\
\text { for the ecology of the area or region. }\end{array}$ \\
\hline
\end{tabular}

Factors and criteria established during the first workshop were tested in the field in four different sites of the Colombian coastlines, both in the Caribbean and the Pacific coasts. Descriptions of the different coastlines were performed using the factors and criteria previously discussed which were later grouped and assigned to preliminary index values.

\section{Determination of Factors and Criteria for ESI Construction}

Three basic criteria were proposed for the construction of the ESI: geomorphology of the coast line, which determines the natural recovery of the area; possibility of implementation of cleaning techniques, allowing the recovery of oil and avoiding further damages; and ecological importance of the ecosystems present, determining the biodiversity at risk from an oil spill (Table 1).

These three basic criteria allowed the identification of eight (8) factors used to allocate a degree of sensitivity for the different types of coastlines present in the country. Table 2 shows these eight factors and ranks used to evaluate and classify the sensitivity to oil spills of different types of coastlines based on their geomorphologic, hydrodynamic characteristics.

Evaluation factors are:

\section{Artificial Substrate}

Man-made structures on the coastline (Figure 1a and $1 \mathrm{~b}$ ). Compact structures (i.e. concrete walls) are considered less sensitive than structures with crevices (i.e. wave breakers) since the latter offer refuge to organisms and oil is difficult to clean from these structures (NOAA, 2002; Gundlach, 2006).
Table 2. Factors defined to evaluate coastline sensitivity to oil spills.

\begin{tabular}{|c|c|}
\hline Factors & Ranges \\
\hline \multirow{5}{*}{ Natural substrate } & Bedrocks \\
\hline & Boulders \\
\hline & Rubble and Pebbles \\
\hline & Sand \\
\hline & Mud flats \\
\hline \multirow{2}{*}{ Artificial substrate } & Compact structures \\
\hline & Non compact structures (with crevices) \\
\hline \multirow{4}{*}{ Permeability* } & Non-permeable \\
\hline & Semi-permeable \\
\hline & (Oil penetration into sediment $<50 \mathrm{~cm}$ ) \\
\hline & $\begin{array}{l}\text { Permeable } \\
\text { (Oil penetration into sediment }>50 \mathrm{~cm} \text { ) }\end{array}$ \\
\hline \multirow{3}{*}{ Slope } & $\operatorname{High}\left(>30^{\circ}\right)$ \\
\hline & Medium $\left(5^{\circ}-30^{\circ}\right)$ \\
\hline & $\operatorname{Low}\left(<5^{\circ}\right)$ \\
\hline \multirow{2}{*}{ Tide range } & Narrow \\
\hline & $\begin{array}{l}\text { (Non-formation of mud or sand flats) } \\
\text { Ample (Formation of mud or sand flats) }\end{array}$ \\
\hline \multirow{2}{*}{ Wave exposure } & Exposed \\
\hline & Protected \\
\hline \multirow{3}{*}{ Biodiversity* } & Low \\
\hline & Medium \\
\hline & High \\
\hline \multirow{3}{*}{$\begin{array}{l}\text { Access and transit } \\
\text { on the coastline }\end{array}$} & Possible \\
\hline & Moderated \\
\hline & Not possible \\
\hline
\end{tabular}

*Valuation established through experts opinion or secondary information.

\section{Natural Substrate}

The degree of sensitivity is mainly determined by the characteristics of the substrates found on the coastline (Figures 1c-1f). The relation between grain size and sensitivity is given by the possibility and depth of oil penetration into the substrate, the potential for burial, and the time that the oil will remain in contact with the substrate and biota, which determines the kind of cleaning technique required; grain size also 
determines the biodiversity present in the coastline. Coastlines with consolidated compact rocks and beaches with fine compacted sand that prevent oil to percolate into the substratum are considered to be less sensitive than beaches of gravel or coarse sand where oil can easily penetrate (Gundlach \& Hayes, 1978; Petersen et al., 2002).

\section{Wave Exposure}

Degree of contact of the coastline with wave action (Figure 2). The energy of waves breaking in the coast may promote the movement of sediments possibly burying the oil, but it can also help in the natural cleaning of the coastline by removing oil from rocks and other surfaces, influencing the persistence of oil in

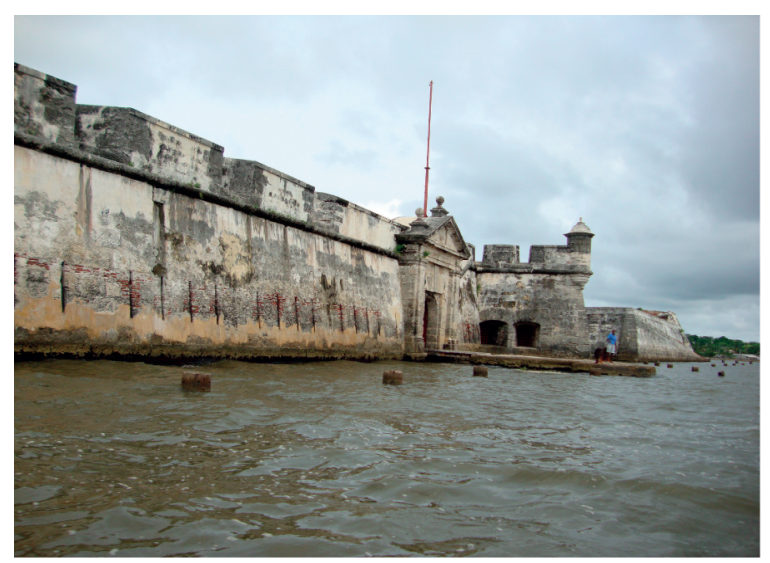

(a)

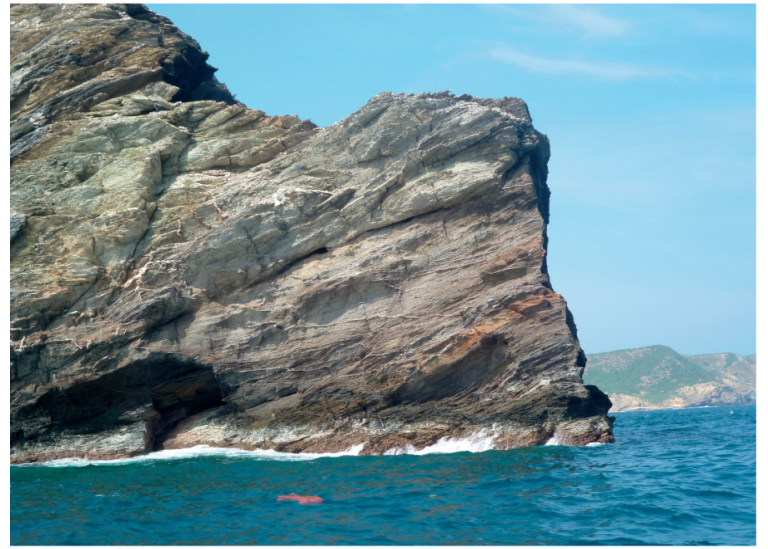

(c)

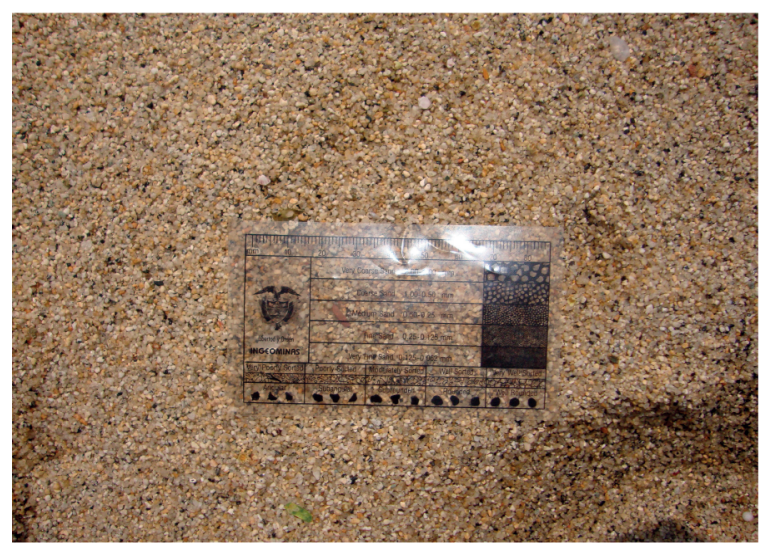

(e)

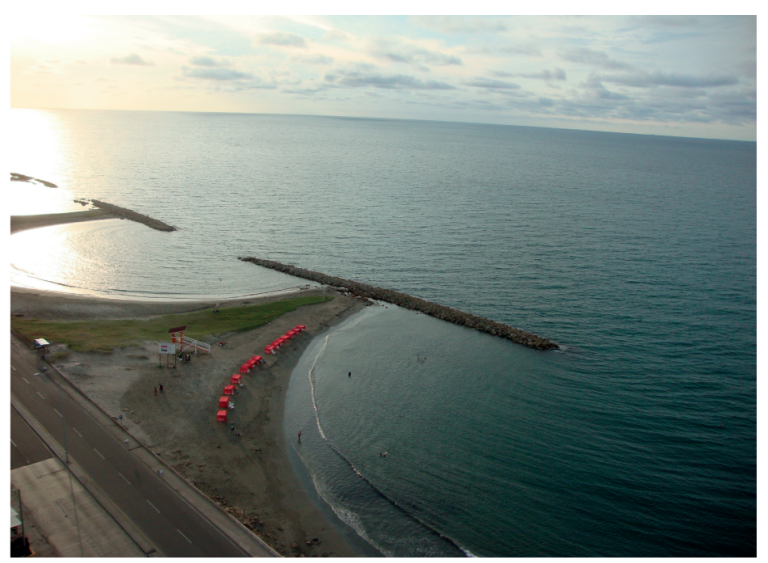

(b)

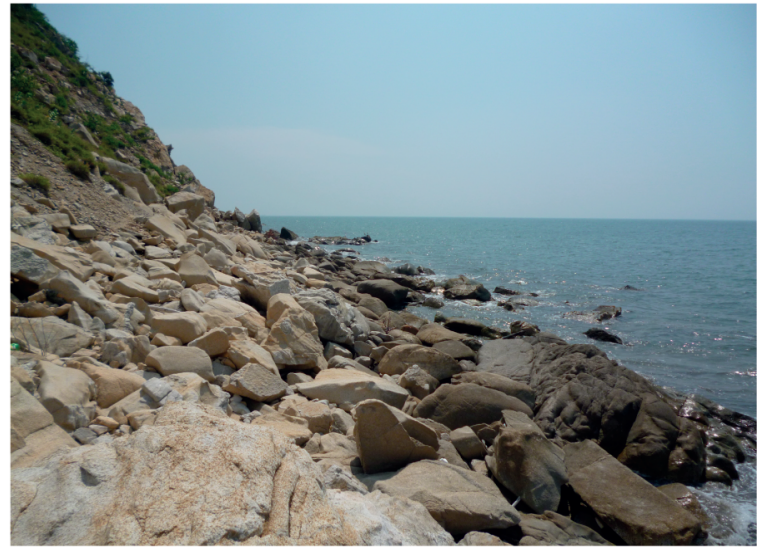

(d)

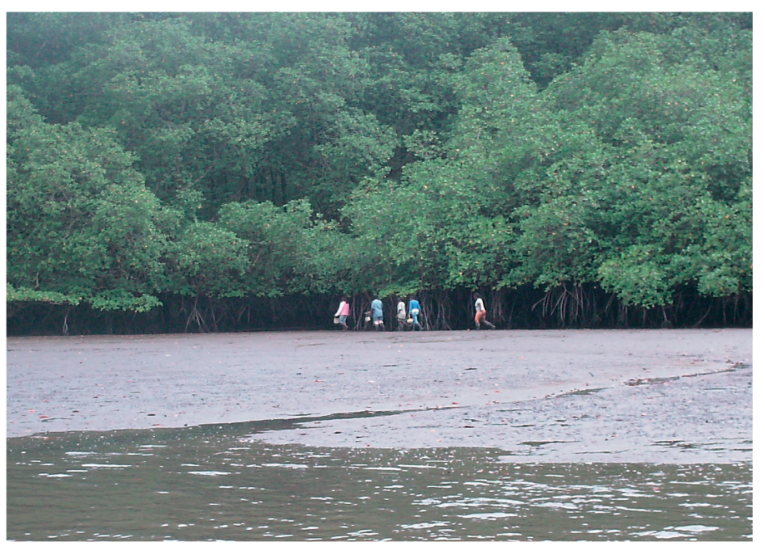

(f)

Figure 1. Substrate type as a factor that conditions the level of sensitivity of coastlines to oil spills. Artificial Substrate: (a) concrete walls, (b) wave breakers. Natural Substrates: (c) compact rocky shores, (d) rubble, (e) sands, (f) mud flats. 
the ecosystem. Protected coastlines are deemed more sensitive to oil spills than exposed coastlines, since this oil is not naturally removed from the system by wave energy. Protected coastlines are those where structures, such as sand bars, fringing reefs or others are present in front of the coastline and dissipate the energy of the waves (Petersen et al., 2002; SQA/MMA, 2004; Gundlach, 2006).

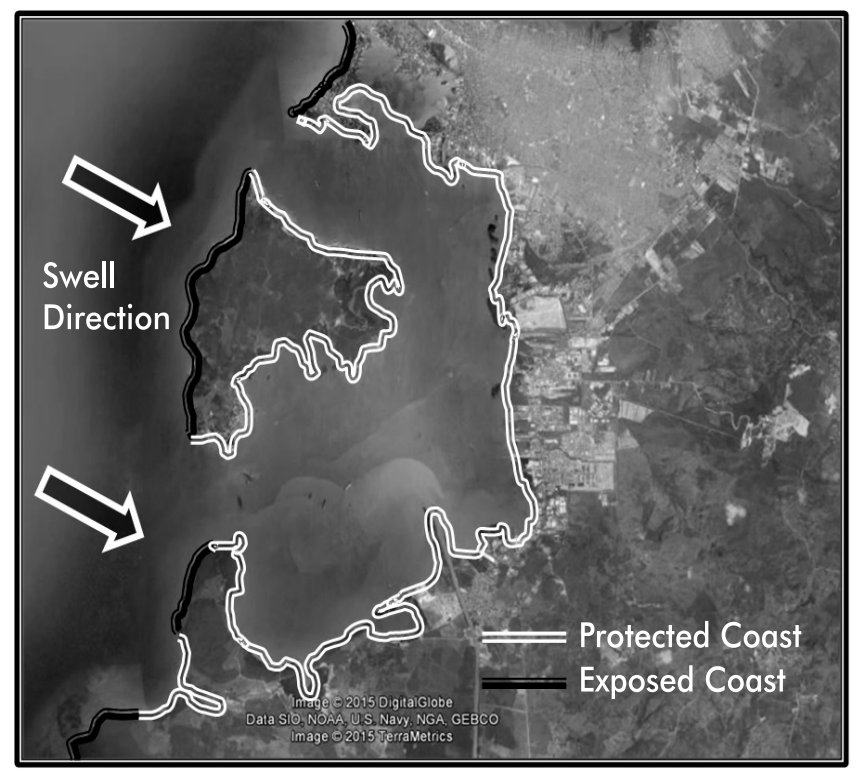

Figure 2. Wave exposure, factor that contributes to the sensitivity of coastlines to oil spills.

\section{Tidal Range}

This factor is important to establish the amplitude of the coastline and, as such, the area potentially exposed to the impact of oil spills; it also generates changes in the hydrodynamic processes of the coast (Figure 1f). The formation of wide beaches or mud flats due to large tidal ranges results in a large area potentially impacted that has to be cleaned (Petersen et al., 2002; SQA/MMA, 2004).

\section{Slope}

Angle of the coastline related to the horizon. This factor determines the energy of waves breaking into the shore promoting the natural cleaning of the coastline and the movement of sediments, influencing the persistence of oil in the area. Slope and tidal range govern the area of coastline potentially exposed to oil spills. It is considered that coastlines with low slopes $\left(<5^{\circ}\right)$ are more sensitive than coastlines with high slopes $\left(>30^{\circ}\right)$ (Petersen et al., 2002).

\section{Permeability}

Penetration of oil into the substratum through the interstitial pores of the sediment. Cleaning techniques to be used are in part determined by this condition since removal of large quantities of sediment might be necessary in highly permeable substrates. Nonpermeable substrate (i.e. consolidated rock) are less sensitive than semi-permeable (penetration $<50 \mathrm{~cm}$ ) and highly permeable substrates (penetration $>50 \mathrm{~cm}$ ) (Petersen et al., 2002; SQA/MMA, 2004).

\section{Biodiversity}

Areas with high (mangroves, coastal lagoons, etc.) or moderate (mud flats, crevices, areas protected from wave action, etc.) biological diversity are more sensitive to oil spills than areas with relatively low diversity (coarse sand beaches, rocky shores with high wave action) (Gundlach \& Hayes, 1978; Petersen et al., 2002; SQA/MMA, 2004).

\section{Accessibility of the Coastline}

Complexity of the coastline that determines how difficult will be for cleaning crews to access and transit the coastline to reach and work on the oil spill without causing more impacts to the environment. Areas where cleaning activities can be easily performed (i.e. wide beaches with fine sand) are considered less sensitive than areas with restricted accessibility, areas that might pose risks for the cleaning crew or areas where cleaning activities might result in further damage to the environment (high energy beaches or rocky shores, mangroves, etc.) (Petersen et al., 2002; SQA/MMA, 2004).

During the second workshop results of this first effort to establish an ESI were submitted to the experts and resulted in the construction of the definitive ESI for Colombian coastline.

\section{RESULTS}

\section{ESI for Colombian Coastlines}

A total of 16 different types of coastlines were identified and evaluated with the previously mentioned factors that were later grouped into 10 different categories for the ESI (Tables 3 and 4). Lower ESI values corresponded to less sensitive coastlines, while high values correspond to coastlines and ecosystems with high sensitivity. 


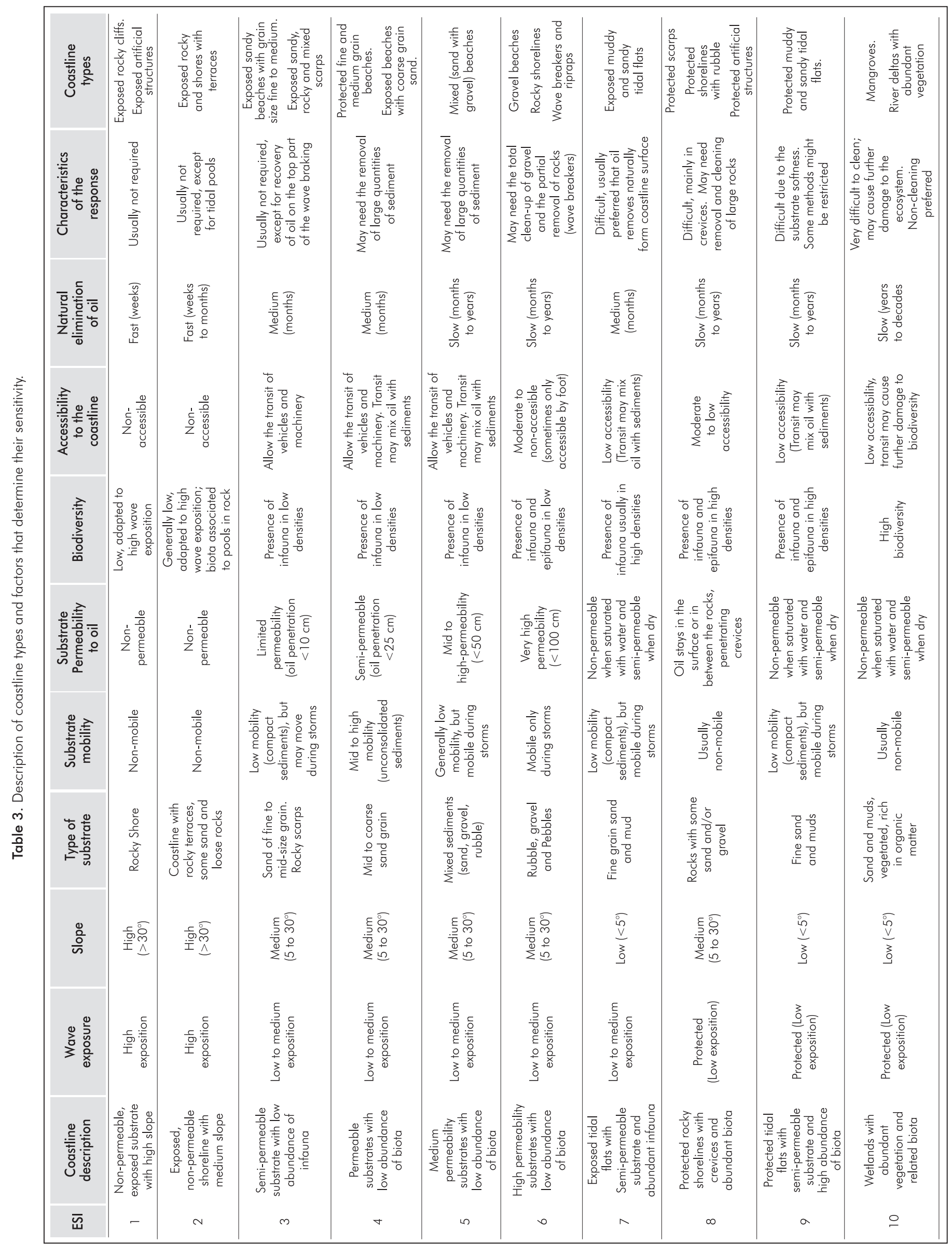


Table 4. Levels of sensitivity to oil spills of different Colombian coastline types.

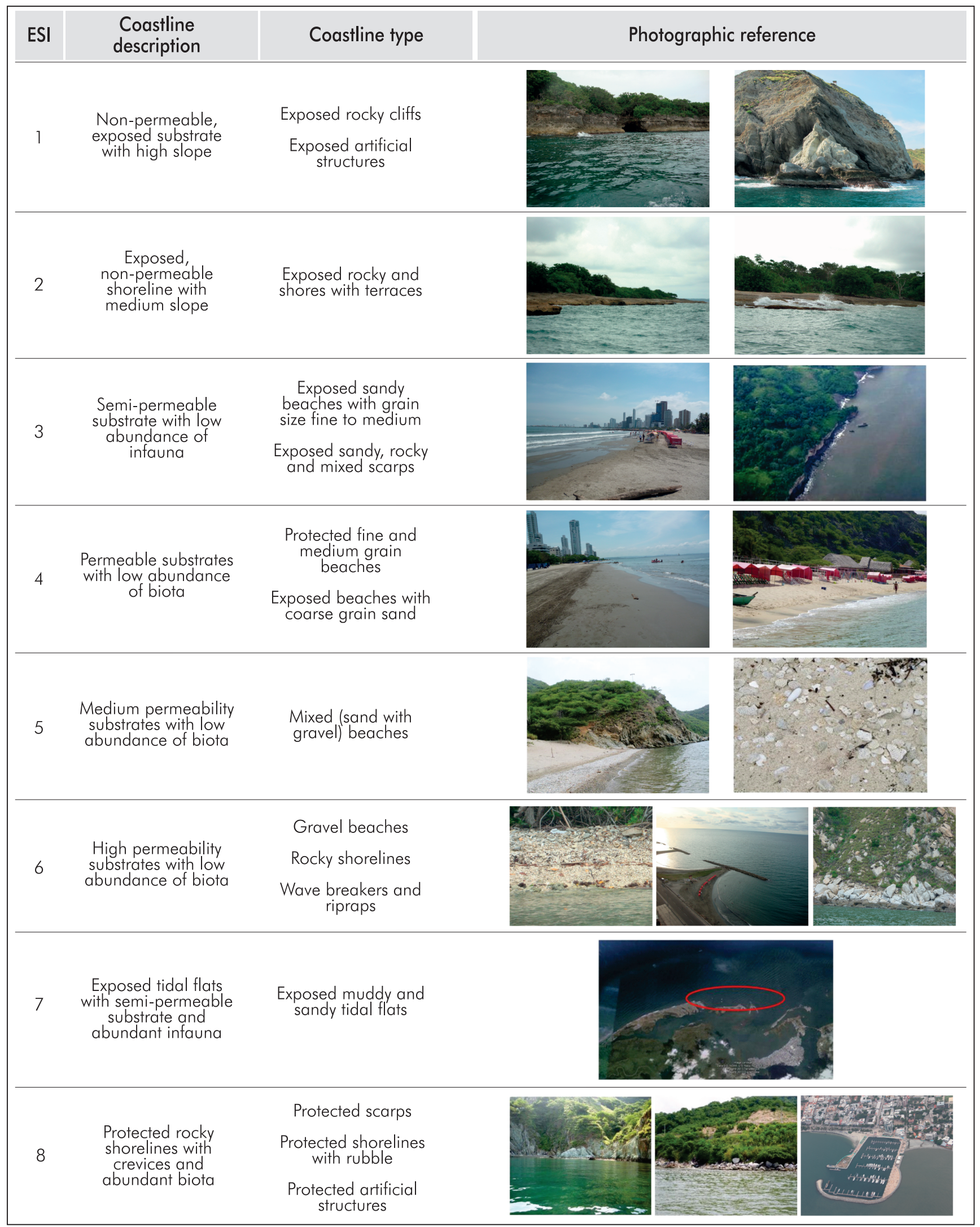


Table 4. Levels of sensitivity to oil spills of different Colombian coastline types. (Cont.)

\begin{tabular}{|c|c|c|c|}
\hline ESI & $\begin{array}{c}\text { Coastline } \\
\text { description }\end{array}$ & Coastline type & Photographic reference \\
\hline 9 & $\begin{array}{c}\text { Protected tidal flats } \\
\text { with semi-permeable } \\
\text { substrate and high } \\
\text { abundance of biota }\end{array}$ & $\begin{array}{c}\text { Protected muddy and } \\
\text { sandy tidal flats }\end{array}$ \\
10 & $\begin{array}{c}\text { Mangroves } \\
\text { abundant vegetation } \\
\text { and related biota }\end{array}$ & $\begin{array}{c}\text { River deltas with } \\
\text { abundant vegetation }\end{array}$ \\
\hline
\end{tabular}

Coastlines with ESI 1 and 2 correspond to rocky shores or shorelines composed of cliffs with compact rocks, clay or other impermeable materials that prevent oil from penetrating the substrate, high slope $\left(>30^{\circ}\right)$, high wave exposure and biota represented mainly by organisms capable of withstanding the force of waves breaking into the coast. The action of high wave energy into the coastline prevents oil from reaching the shoreline or when it does arrive, it helps to quickly remove it from the substrate (weeks). Also, low biological diversity of these areas and its high natural recoverability makes ecological impact smaller. Intervention of cleaning crews in these areas is minimal due to the low impact and difficulties and risk to the personnel.

ESIs 3 through 6 correspond to sand, gravel or mixed beaches as well as coastlines with ripraps with a slope of less than $30^{\circ}$, usually exposed to wave energy. These kinds of coastlines have mid to high permeability and biological communities are present in low densities, so the potential ecological impact remains low, but the natural recovery happens at a lower rate (months to years) than in ESIs 1 and 2 (IPIECA, 2000; Lubick, 2010). Cleaning actions for these areas include flushing sediments, or their partial or total removal.

ESIs 7 and 8 belong to coastlines with a higher biological diversity, mainly infauna that live in mudflats created by tides and in protected environments with hard substrates with crevices, including artificial substrates. These areas are difficult to access and clean, and cleaning actions can cause further damage to the environment, reason why it is important to prevent or minimize the arrival of oil to these areas.
Finally, higher ESIs (9 and 10) are reserved for areas with high sensitivity, mainly because they are home to a high biodiversity. These areas are mainly vegetated river mouths, coastal lagoons and mangroves, areas of high ecological importance with low wave energy where natural recovery from oil impacts can take years to decades. Cleaning oil from these areas might usually cause additional damage to the environment, which is why it is important to protect these environments from oil exposures. Ecosystems like coral reefs are not represented by the index since they are submerged, except in the case of coral crest or fringing reefs located very close to the water surface.

\section{DISCUSSION}

For more than 30 years, different countries around the world have created or adapted methodologies to classify coastline sensitivity to oil spills as a tool for the prevention and response against oil spills (Jensen et al., 1998).

In Colombia, the only prior case of constructing an ESM was attempted by Tejada and Afanador (2003); nonetheless, these authors used the same ESI classification used by NOAA instead of adapting it to local ecosystems and conditions, as recommended by IPIECA (2011) and other organizations.

Most of the basic concepts of this work where extracted from methodologies used by Petersen et al. (2002) and the Ministry of Environment of Brazil (SQA/ MMA, 2004), which are the most developed methods 
for ESI. However, workshops with experts where fundamental for construction of an ESI for Colombia that can be applied to the entire country and that can be used for the creation of ESM or other oil spill contingency tools (Figure 3). Also, the participation of experts from different areas (industry, academia, government) in the ESI construction legitimize the process and results and guarantee its application and acceptance by different stakeholders. Results of the ESI for Colombia has coincidences with ESIs from NOAA and the Ministry of Environment of Brazil, especially in the lower and higher ends of the index; nonetheless, differences are evident in the intermediate levels, since the classification is influenced by factors such as the coastline accessibility and response characteristics. The most noticeable difference is found in index 8 , where protected artificial structures were included by the expert panel mainly due to the social and economic impacts that an oil spill might produce.

Having a standardized ESI for Colombia paves the way for a fast and easy application of tools such as ESM, contingency plans, contingency maps, and others that are largely based in this index. It also allows different companies and organizations to develop these kinds of tools for their particular area of interest that can be shared and used by other organizations or government entities.

\section{ACKNOWLEDGEMENTS}

Authors wish to express their gratitude to Ecopetrol $S$. A. for the funding provided for this project. Also, we would like to acknowledge the different organizations and experts that participated in the workshops, especially Shell and Shell Global Solutions for sharing their expertise in this area. Finally, special thanks to Dr. Darío Miranda for his suggestions to this project.

\section{REFERENCES}

Adler, E. \& Inbar, M. (2007). Shoreline sensitivity to oil spills, the Mediterranean coast of Israel: Assessment and analysis. Ocean Coast. Manage., 50(1-2), 24-34.

ARPEL (1997). Guía para el desarrollo de mapas de sensibilidad ambiental para la planificación y respuesta ante derrames de hidrocarburos. Ottawa, $50 \mathrm{pp}$.
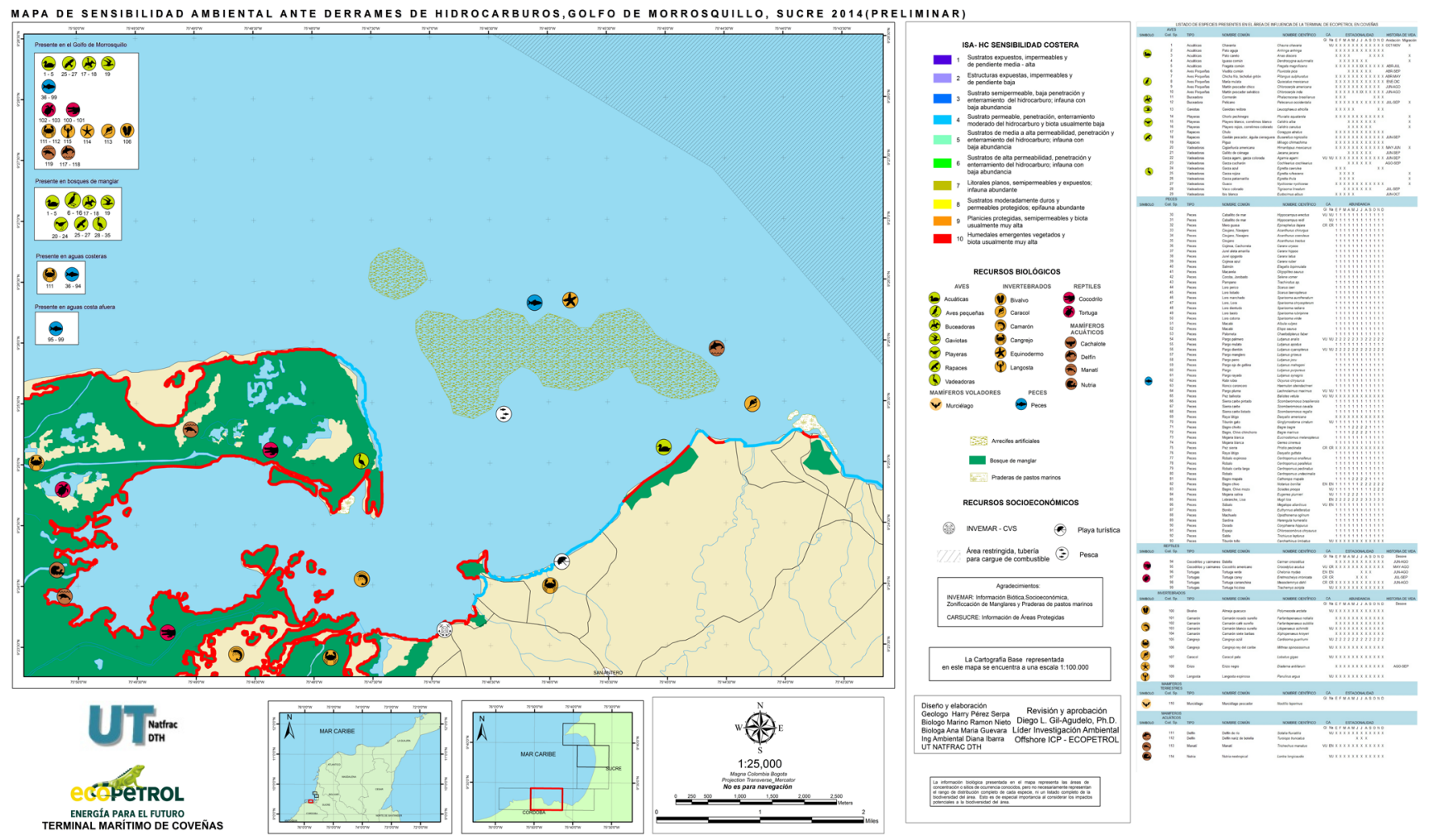

Figure 3. Application of Environmental Sensitivity Index (ESI) to Environmental Sensitivity Map (ESM) in an area of the Colombian Caribbean. 
Castañedo, S., Pombo, C., Fernandez, F., Medina, R., Puente, A. \& Juanes, J. A. (2008). Oil spill vulnerability atlas for the Cantabrian Coast (Bay of Biscay, Spain). IOSC Proceedings, 1: 137-144.

Clark, J. R. (1995). Coastal zone management handbook. London: Lewis Publishers.

GESAMP (2007). Estimates of oil entering the marine environment from sea-based activities. Rep. Stud. GESAMP, 75: 96pp.

Gil-Agudelo, D. L. \& Wells, P. G. (2011). Impacts of landbased marine pollution on ecosystems in the Caribbean sea. Implications to EBM approach in the Caribbean. In: Fanning, L., Mahon, T. \& McConney, P. (Eds.) Towards marine ecosystem-based management in the wider Caribbean. Amsterdam University Press, Vol. 6. 69-83.

Griggs, J.W. (2011). BP Gulf of Mexico oil spill. Energy L. J., 32(1), 57-80.

Gundlach, E. R. (2006). Oil spills: Impacts, recovery and remediation. J. Coast. Res., 39: 39-42.

Gundlach, E. R. \& Hayes, M. O. (1978). Vulnerability of coastal environments to oil spill impacts. Mar. Technol. Soc. J., 12(4), 18-27.

Gundlach, E. R., Imevbore, V. O., Witherspoon III, B. \& Ainodion, J. (2001). Incorporating biodiversity into sensitivity maps of the Niger River Delta. IOSC Proceedings, 2001: 391-397.

IPIECA. (2000). Impactos biológicos de la contaminación por hidrocarburos: Costas sedimentarias. Serie de Informes de IPIECA, Volumen nueve. Blackfriars Road. Londres, Reino Unido.

IPIECA-IMO-OGP. (2011). Sensitivity mapping for oil spill response. IMO/IPIECA Report Series, Volume One. Blackfriars Road. London, United Kingdom.

Jensen, J. R., Halls, J. N. \& Michel, J. (1998). A systems approach to Environmental Sensitivity Index (ESI) mapping for oil spill contingency planning and response. Photogramm. Eng. \& Remote Sens., 64(10), 1003-1014.

Lubick, N. (2010). Why oil from the Exxon Valdez lingers. Rocky beaches may have locked oil away in airtight pores.
Nature. [Online]. 17 January. Available at: <http://www. nature.com/news/2010/100117/full/news.2010.16.html>

Nansingh, P. \& Jurawan, S. (1999). Environmental sensitivity of a tropical coastline (Trinidad, West Indies) to oil spills. Spill Sci. Technol. Bull., 5(2), 161-172.

Petersen, J., Michel, J., Zengel, S., White, M., Lord, C. \& Plank, C. (2002). Environmental sensitivity index guidelines, Version 3.0. NOAA Technical Memorandum NOS OR\&R, 11, 192pp.

Secretaria de Qualidade Ambiental, Ministério do Meio Ambiente, Brasil (SQA/MMA). (2004) Especificações e Normas Técnicas para Elaboração de Cartas de Sensibilidade Ambiental para Derramamentos de Óleo/ Ministério do Meio Ambiente. Secretaria de Qualidade Ambiental nos Assentamentos Humanos. Programa de Gerenciamento Ambiental Territorial. Projeto de Gestão Integrada dos Ambientes Costeiro e Marinho. Brasília: Ministério do Meio Ambiente, 107pp.

Tejada, C. \& Afanador, F. (2003). Evaluación del riesgo debido a derrame de hidrocarburos en la bahía de Tumaco. Boletín Científico CCCP, 10: 56-82.

Upton, H. F. (2011). The deepwater horizon oil spill and the Gulf of Mexico fishing industry. CRS Report for Congress. Congressional Research Service. 7-5700. R41640.

\section{AUTHORS}

\section{Diego L. Gil-Agudelo}

Affiliation: Ecopetrol S.A.-Instituto Colombiano del Petróleo (ICP) Marine Biologist, Universidad Jorge Tadeo Lozano Spe., Dalhousie University $\mathrm{Ph}$. D. in Marine Science, University of South Carolina e-mail: diego.gil@ecopetrol.com.co

\section{Ramón-Alberto Nieto-Bernal}

Affiliation: CTP LTDA

Marine Biologist, Universidad Jorge Tadeo Lozano

e-mail: ramonnieto2000@yahoo.es

\section{Diana-Marcela Ibarra-Mojica}

Affiliation: CTP LTDA

Sanitary and Environmental Engineering, Universidad Pontificia

Bolivariana

e-mail: dibarramojica@gmail.com 
Ana-María Guevara-Vargas

Affiliation: CTP LTDA

Biologist, Pontificia Universidad Javeriana

e-mail: anicolombia2007@gmail.com

Erich Gundlach

Affiliation: E-Tech International Inc.

Marine Biologist, University of South Carolina

$\mathrm{Ph}$. D. in Marine Science, University of South Carolina

e-mail: ErichEti@cs.com 